\section{KATE O'BRIEN: ESPAÑA CON VOZ DE MUJER}

KATE O'BRIEN: SPAIN WITH A FEMALE VOICE

Daniel Pastor García Universidad de Salamanca

Resumen:

Abstract:

Kate O'Brien es una importante autora en la Kate O'Brien is an important writer in the literatura irlandesa actual. Sus obras reflejan current Irish literatura. Her works reflect the la realidad de mujeres que se enfrentan a reality of women who face a conservative and una sociedad conservadora y patriarcal. Su patriarchal society. Her close relationship cercana relación con España hizo que dos de with Spain made two of her novels take the sus novelas se inspiraran en este país, Mary inspiration from this country, Mary Lavelle Lavelle y That Lady. Sus obras muestran a ind That Lady. Her works represent brave Lavelle y That Lady. Sus obras muestran a and That Lady. Her works represent brave mujeres fuertes que van evolucionando a lo women who have evolved throughout their
largo de su vida hasta encontrar su identidad. lives till finding their identity.

Palabras claves:

\section{KeY WORD:}

Kate O'Brien, Spain, woman.
En los últimos veinte años Kate O'Brien ha pasado de ser una gran desconocida a convertirse en una de las figuras clave de la literatura irlandesa contemporánea. Su obra suscita ahora un enorme interés dentro y fuera de Irlanda por el tono franco $\mathrm{y}$ anticonvencional de algunos de los temas que trata y en especial por su retrato de mujeres que hacen frente a las limitaciones de una sociedad extremadamente conservadora e intolerante. Si hay algo que impactó de manera muy significativa en su carrera literaria fue su intensa y prolongada relación con España hasta el punto de que le serviría de verdadera inspiración en dos de sus novelas más conocidas de las nueve que escribió, Mary Lavelle (1936), que trata de las complejidades morales y psicológicas de una joven irlandesa hasta lograr el verdadero desarrollo de su propia personalidad, y That Lady (1946), que aborda la influencia corruptora del poder político y la resistencia heroica de una mujer al despotismo de Felipe II. Escribió también en 1937 un magnífico libro de viajes titulado Farewell Spain, y en 1951 una de las mejores biografías de la lengua inglesa de Santa Teresa de Jesús titulada Teresa de Ávila, además de relatos cortos y reportajes periodísticos. Desde que a mediados de 1922 viajara por primera vez a Bilbao para trabajar durante casi un año como institutriz para los hijos de una conocida familia vasca, se sintió cautivada por un lugar y unas gentes que inmediatamente hizo suyas, pero es a partir de 1930 y hasta el comienzo mismo de la guerra civil cuando España se convirtió de manera ininterrumpida en su destino habitual cada verano. Ella misma proporcionó una explicación a su relación:

Fatal attraction between persons is an old poets' notion that some of us still like to is possible and occasional, though no probable - and Spain seems to me to be the femme fatale among countries. Though many would claim that for lovely France. For me, however, it has been Spain. So true is this that I have hardly seen any other countries. Always I go back over the Pyrenees. My love has been long and slow-lazy and selfish too, but I know that wherever I go henceforward and whatever I see I shall never again be able to love an earthly scene as I have loved the Spanish ... with Spain I am once and for all infatuated. With curious fidelity - for I am fickle. (1985: 227)

España, en efecto, atrapó su corazón como ningún otro lugar; era la tierra de la belleza mística, de la pasión combinada con la austeridad, y, sin duda, la diversidad geográfica del país, sus contrastes humanos, la enorme fascinación que sintió por Castilla y su pasado histórico y, sobre todo, la lectura de las obras de Santa Teresa, le sirvieron para introducir en su universo literario personajes femeninos valientes, decididos, transgresores, que para nada encajan en las expectativas sociales del momento ni en los roles de género que la sociedad tradicional les ha asignado, y son capaces de resistir o de desafiar el sistema patriarcal de poder, ya sea la familia, la iglesia, o el poder político. La semiautobiográfica Mary Lavelle es la tercera novela de su producción y la primera centrada en España en su totalidad. En ella podemos identificar lo que para algunos constituye el núcleo temático de su narrativa, o sea, "the complex interaction 
of obligation and independence, of home and escape" (Hildebidle: 51). Mary Lavelle, la protagonista, es una hermosa joven que se niega a seguir lo que la tradición y la educación recibida requieren de su condición de hija mayor y, por tanto, cuestiona los principios morales, sociales y familiares que parecían firmemente asentados. Su existencia en una pequeña ciudad de provincias es monótona, vacía, carente de motivaciones. Consume sus días entregada a las tareas domésticas y a satisfacer los caprichos de un padre egoísta y las manías de una tía que se ha hecho cargo de la familia desde la muerte de su madre; nada especial sucede en su vida, y simplemente espera paciente a que John, el respetable joven con el que está prometida en matrimonio, haga la fortuna suficiente para convertirla en la esposa feliz y la madre sacrificada como dictan las buenas costumbres. Pero aunque cree estar enamorada nunca ha sentido verdadera pasión. Casi sin saber muy bien las consecuencias de su decisión, acepta ir a trabajar a España como institutriz, un acto que le permitirá explorar el mundo a su manera y que acabará por transformar radicalmente el curso de su vida. Además cree que su estancia en el extranjero durante un año acabará disipando sus dudas sobre la conveniencia de contraer matrimonio. Irlanda, en definitiva, se muestra para ella como un espacio claustrofóbico, y la imagen que tiene de su insoportable entorno familiar y de su mundo cotidiano le sugieren "... a terrifying peace, a timelessness and changelessness most desolating in their personal call to her" (1984: 142); España, por el contrario, se presenta como un espacio alternativo, privado, donde aprenderá lo que significa el amor, el dolor, la vida misma, y en el que construirá su identidad femenina al margen de las reglas imperantes. En suma, representa la libertad, la posibilidad de escapar de un sentimiento de sumisión total en el marco patriarcal:

To go to Spain. To be alone for a little space, a tiny hiatos between her life's two accepted phases. To cease being a daughter without immediately becoming a wife. To be a free lance, to belong to no one place or family or person - to achieve that silly To be a free lance, to belong to no one place or family or person - to achieve that silly longing of childhood, only for one year...She would be unobserved, uncherished and, she hoped, unreproved. She had in fact put on a cap of invisibility, from under which, however, she could use her unlearned eyes with circumspection and in peace. $(34,37)$

A medida que se integra en su nuevo entorno, la influencia de su mundo familiar se desvanece y adquiere la autonomía de la que carecía hasta entonces. Se siente rodeada de seres fracasados, infelices, como Don Pablo, el padre de sus discípulas, que decepcionado en su matrimonio y en sus opiniones políticas, no ha sabido llevar a cabo sus sueños; o Doña Consuelo y Luisa, las dos mujeres de la familia, que aparecen extremadamente conservadoras e intelectualmente inferiores a sus esposos. Las otras institutrices irlandesas que llega a conocer son vulgares, sin ambiciones, han renunciado a integrarse en España y se sienten amargadas. Una de ellas, Agatha Conlan, lleva una vida doblemente marginada por el hecho de ser lesbiana y atreverse a confesarlo, pero de ella Mary aprende la necesidad de ser siempre valiente sobre todo cuando se trata expresar los verdaderos sentimientos. A diferencia de todas ellas, Mary se siente atraída por nuevas experiencias y poco a poco da rienda suelta a su curiosidad por conocer todo lo que de nuevo el país le ofrece, y desde la fiesta de los toros hasta su descubrimiento de lo que llama la "España inesperada", o sea, los vastos espacios de Castilla, su luminosidad especial y sus gentes, formarán parte de su educación sentimental. El famoso viaje en tren que realiza a Madrid, atravesando la seca y austera meseta castellana, se convierte en una auténtica revelación porque encuentra en el paisaje una belleza distinta, singular, paradisíaca: “here it was, to left and right of her, as gentle as Heaven" (216). Acaba también enamorándose perdidamente de Juanito, el hermano mayor, y se hacen amantes, pero él está felizmente casado y es padre de un niño, y Mary está prometida; ambos son católicos y provienen de países donde no hay divorcio, su unión es imposible y no hay futuro para los dos juntos. Mary ignoraba por completo las sutiles implicaciones del amor y aprende que la naturaleza humana no es libre del todo y que la pasión desinhibida es mucho más poderosa que la fe y las convenciones sociales. Justo en las últimas páginas, Agatha, Conlan, fiel practicante de los ritos de la iglesia católica, insinua su atracción hacia Mary pero inmediatamente se disculpa diciendo "It's a sin to feel like that", a lo que Mary contesta "Oh, everything's a sin! (285) manifestando su fastidio por la excesiva influencia de la moral católica en la vida cotidiana de las personas. Su breve relación amorosa con Juanito no es lo que le va a hacer más fuerte como persona, ni le ayuda a madurar, sino la superación de los obstáculos que tiene que afrontar por sí misma, el conflicto creado por esos momentos de ilusión y realidad, éxtasis y dolor, sentimientos de culpabilidad y de remordimiento. Mary es siempre la que lleva la iniciativa en su relación y asume enteramente las consecuencias de su pasión ilícita:

the central sin against Catholic teaching would be her affair and heavens... she thought of school and home, of John, of God's law and sin, and did not let herself discard such thoughts. They existed as real and true as ever, with all their traditional claims on her-but this one claim was his and she

taking the consequences..." $(257,308)$.

Sus últimos pensamientos, justo antes de la separación definitiva, suenan a triunfo personal:

She had given him all she had, the first and the best of herself, and had taken the pain of love from him, from whom alone she wanted it. She had been his lover. She was content. (312)

La novela termina, en efecto, con su regreso a Irlanda como una mujer nueva, pero no para quedarse sino para reclamar la herencia que su padre injustamente le ha 
retenido, y así, liberada de la influencia paterna y de la obligación de llevar a cabo una unión con su prometido en la que nunca creyó del todo, emprender una vida propia en el exilio, más fortalecida y preparada, manteniendo su deseo de "perpetual selfgovernment" (27). Mary Lavelle fue prohibida en Irlanda por su contenido inmoral entre otras poderosas razones:

What shocked our moral guardians so much was not that here was a flagrant instance of sex outside of marriage, but that the girl was not hounded into it, that she was the one to choose, that she knew her lover was married,
that she had deliberately, from their point of view, wrecked her whole life, that she had taken the shadow for the that she had deliberately, from their point of view, wrecked her whole life, that she had taken the shadow for the
substance. Irish girls did not behave that way, or if they did, other girls must not hear about it. (Reynolds: 184)

Mary Lavelle además de una hermosa novela de amor es también una obra de observación de costumbres sociales. La joven protagonista es testigo directo de una España turbulenta y prerrevolucionaria, y el retrato que ofrece del país en 1923, cuando tiene lugar la acción, es de desolación y de miseria, dominado por un sentimiento generalizado: "nothing could be worse than the present state of Spain" (135), anticipándose a los trágicos tiempos que le tocaría vivir. Su publicación coincidió con el comienzo de la guerra civil española, un acontecimiento que impactó de tal manera a Kate O'Brien que entre octubre de 1936 y febrero de 1937 escribió Farewell Spain, su propia respuesta ante lo que amargamente percibe como "... a country now in agony" (1985: 122). El libro es un conjunto de reflexiones basadas en los viajes que realizó antes del estallido bélico en compañía de su amiga Mary O'Neill, que giran en torno al legado cultural y artístico del país amenazado ahora por la destrucción y la barbarie que se ciernen a causa del conflicto. Es, por tanto, una mirada retrospectiva de su vida y una "self-narrative" donde pone al descubierto sus emociones, preferencias y temores particulares que en buena medida inspiraron sus obras de carácter español. Farewell Spain se convierte así en la celebración nostálgica de edificios, cuadros, ciudades, paisajes, gentes, costumbres, tipos de comida, la misma idiosincrasia española, etc., para los que proporciona datos estéticos, históricos o anecdóticos, pero lo más importante es su intencionalidad, los motivos que la inducen a representar España y lo que significa. Frente al turismo moderno, masificado, impersonal, que inducido por la publicidad promete "the poster world, a world of gamboge and cerulean blue, of singing and lounging and carnations in the mouth... a fantasy ....which has never really died" (1985: 24), Kate O’Brien se propone asumir “ an escapist search for novelty, individualism or the past... pleasure-trips for idle pleasure seekers" (3), y lo que nos ofrece son brillantes momentos del pasado, de todo aquello que significa permanencia, belleza y tradición cuya contemplación produce placer y da sentido a la vida, frente a momentos más siniestros, vulgares e intimidatorios del presente dominado por una guerra cruel que está ensangrentando el país. Se presenta, pues, como una figura anacrónica o "a sentimental traveller" que lucha a su manera frente a la superficialidad de las modas foráneas que están invadiendo "Spain's native taste, grave, common-sense, individual" (183), y no se deja influir por prejuicios, charla animadamente con la gente, fuma y bebe a solas en las terrazas, y sabe disfrutar de cada momento de su experiencia en España a diferencia de su compañera de viajes, Mary O’Neill, "la rubia” como la llaman con admiración las jóvenes de los lugares por donde pasan, que ilustra "the superficiality of the Spanish beauty ideal" (Napier: 32), sólo se muestra interesada en lo más efímero o banal, no sabe apreciar las corridas de toros, se queja de las incomodidades de los hoteles o asume una actitud sensiblera ante los niños mendigos. No se limita, pues, a reproducir la realidad mecánicamente sino que la interpreta, y lo que la distingue de otras escritoras que descubrieron España a raíz de la guerra, es que establece un dialogo con la rica tradición cultural de nuestro país que evoca con pasión ante la devoción exagerada del mundo contemporáneo a la ciencia, "the universal dictador" (4). Por esta razón dedica un amplio apartado a su gran heroína, a Santa Teresa, la mujer que ganó su admiración incondicional y en cuya personalidad excepcional descubre todo un catálogo de cualidades que enumera con entusiasmo:

\section{She was everything-preacher, teacher, lawyer, cashier, politician, poet, tramp and charwoman. She was the best cook in all her convents... a formidable match for inquisitor or Salamancan doctor. She was a fighter and a schemer, a soldier and most subtle diplomat...She was a communist: 'Let no sister have anything of her own but everything in common and to each be given according to her need. Neither must the prioress, etc. all must be equal" This is her eternal cry up and down Spain. She was a feminist: "I will not have my daughters women in anything but Spain. She was a feminist: "I will not have my daughters women in anything, but valorous men"....She was the last of her kind...the greatest woman in Christian
history (109-113)}

Para Kate O'Brien representaba a la mujer que luchó por las cosas en las que creía. En las difíciles circunstancias que atraviesa el país seguramente estaría ahora al lado de la soberanía popular, defendiendo con todas sus fuerzas la equidad y la justicia, lo que hace que el ideal comunista se equipare con lo que ella misma practicó de manera sistemática a lo largo de su vida. Además, su naturaleza indomable le sirvió para hacerse poderosa en un mundo de varones, y no dudó en plantar cara a los grandes que detentaban el poder. Aunque tradicionalmente se la muestra como modelo de sumisión y acatamiento, Kate O’Brien prefiere descubrir su lado más contestatario y disconforme:

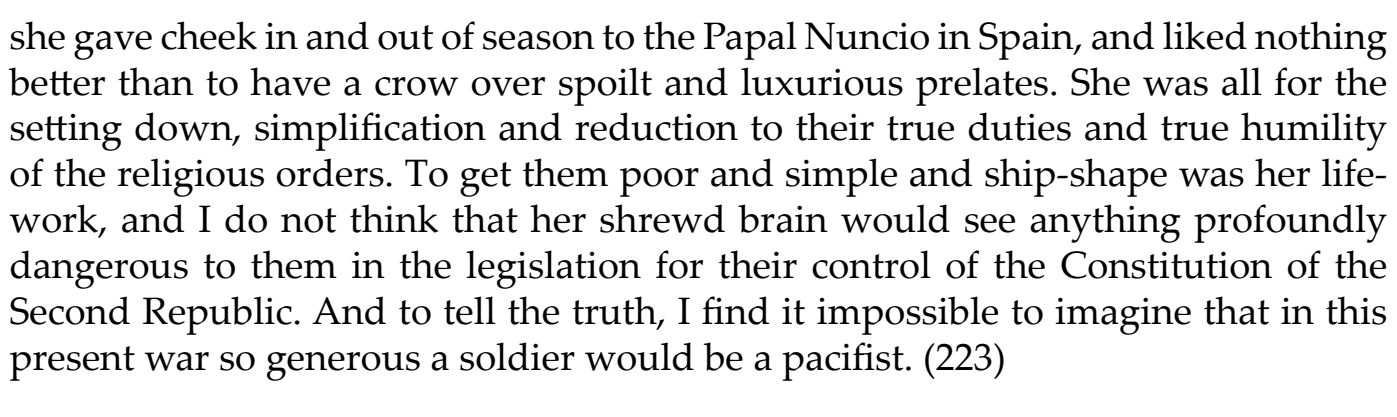

she gave cheek in and out of season to the Papal Nuncio in Spain, and liked nothing better than to have a crow over spoilt and luxurious prelates. She was all for the ( dangerous to them in the legislation for their control of the Constitution of the Second Republic. And to tell the truth, I find it impossible to imagine that in this present war so generous a soldier would be a pacifist. (223) 
Pero, por otro lado, aunque Farewell Spain no tiene un marcado tono político, no es en absoluto indiferente a la tragedia que está viviendo el pueblo español. Los títulos de algunos capítulos como "No Pasarán", donde hace una exaltación de los numerosos atractivos de Madrid, y el menos afortunado "Arriba, España!", donde lanza un duro ataque a Franco, son un compendio de breves comentarios personales a propósito del impacto de la guerra que intercala con la descripción de sus viajes. Su posición está inequívocamente a favor del gobierno legítimo de la República, y de paso aprovecha para expresar su horror, su indignación y su rabia condenando el levantamiento militar:

I am not a Communist, but I believe in the Spanish Republic and its constitution, and I believe in that Republic's absolute right to defend itself against military Juntas, the Moors and all interfering doctrinaires and mercenaries....... war such as General Franco's, openly aimed at the murder of every democratic principle, and for the setting up of his little self as yet another Mussolini-such a war strike , not merely for the death of Spain, but at every decent dream or effort for humanity everywhere. It kills not only the slow, creeping growths, the sensitive plants of social and economic justice... but it sterilises the whole future. Makes it practically impossible to begin again. In short, if the Mussolini-Hitler idea is to win in Europe then it is good-bye to all humanity's small, patient, but once living hopes of universalised decency of life. $(123,221)$

En el fondo, el conflicto bélico español es un signo más de una época convulsa que está acabando con la esencia misma del hombre y sus ideales más nobles. Para ella, pues, viajar no sólo es rescatar del olvido valores imperecederos del espíritu humano sino, sobre todo, una forma metafórica de expresión individual ante los dos sistemas políticos totalitarios imperantes; es también reivindicar una forma de ver y de entender el mundo que discrepa radicalmente del uso de la fuerza y de la violencia, de todo aquello que presagia muerte y destrucción, lo que llama "the universal terrors of nationalisms, dictatorships and race-antipathies...." (6).

No es difícil de imaginar que debido a la contundencia de su rechazo al golpe militar, Farewell Spain fuera un libro condenado por el régimen franquista, Kate $\mathrm{O}^{\prime}$ Brien fuera calificada de persona no grata e incluso se le prohibiera la entrada en España hasta 1957 cuando gracias al embajador irlandés se le permitió regresar de nuevo después de más de 20 años de ausencia. Pese a todo, su interés por España no decayó en absoluto. De profundas convicciones pacifistas, defensora a ultranza de los derechos y de la libertad individual por encima de todo, y en parte como respuesta al desolador panorama europeo por la devastadora guerra mundial y por los regímenes dictatoriales del momento, Kate $\mathrm{O}^{\prime}$ Brien dedicó toda su atención a escribir la novela que más éxito le proporcionó de su carrera literaria, That Lady (1946), ambientada en la España del siglo XVI e inspirada en la figura de Ana de Mendoza, princesa de Éboli, el personaje femenino más controvertido y relevante de la corte de Felipe II, y también uno de los más desventurados. La trama se basa en un enigmático suceso histórico que manipula a su antojo: el turbio asesinato del secretario del rey Juan de Escobedo. Ana de Mendoza fue amiga y confidente del rey y cuando quedó viuda del influyente ministro y secretario Ruy Gómez comenzó una relación con el libertino Antonio Pérez, hombre de confianza de su difunto marido y por entonces también secretario de Felipe II. Al parecer, la pareja intrigó contra el monarca y, según algunos indicios, se vio involucrada en la desaparición de Escobedo. Felipe II, celoso de sus relaciones, les arrestó y Ana fue encarcelada los últimos catorce años de su vida sin poder disponer de sus propiedades ni de la custodia de sus hijos. A partir de este incidente que nunca ha sido aclarado del todo, Kate O'Brien elabora una preciosa novela histórica en la que muestra a una mujer que defiende a ultranza su derecho a tomar ella misma las decisiones que atañen a su vida privada; Ana, en efecto, sólo aparece culpable del amor apasionado que siente por Antonio Pérez, su amante, y para nada está dispuesta a ceder ante las presiones ni siquiera ante las del monarca ni a dejarse manipular ni mucho menos confesar su implicación en la muerte de Escobedo. Así lo hace saber en uno de sus encuentros con el monarca:

I have done no harm to Ruy's memory or my children's name....But, my private life is truly private. There have been, Philip, as long as I can remember, thoughts and even acts in that and even acts in that private life which, presented to the world, would seem to injure this or that. That is so, I should think, for everyone from cradle to grave. But I do not present my private life to the world. I own it, Philip. If I do wrong in it, that wrong is between me and Heaven. But here below, so long as I don't try to change it into public life, I insist that I own it. Not Ruy's memory, and not my children's name... But my private life is all that I own, and I insist on managing it myself, under God. (That Lady: 236)

En la novela se destaca su carácter orgulloso y altivo pero también voluble, rebelde y apasionado. Fue una mujer de la que se dice que no se amilanaba ante nada y ante nadie, y no es de extrañar, por tanto, que chocase con el magnánimo temperamento de Santa Teresa, otra gran mujer, valiente y emprendedora, que todo el mundo respeta y admira excepto la viuda aristócrata. Ana tuvo una relación tensa con la santa sobre todo cuando le ayudó en la fundación de dos conventos carmelitas en Pastrana, un hecho que acabó provocando serios enfrentamientos entre ambas. Precisamente uno de los momentos más interesantes de su vida, que la novela desarrolla, es su intento de hacerse monja carmelita a la muerte de su marido ingresando en uno de los conventos fundados. Acostumbrada a ejercer su voluntad a su antojo, no oculta su total antipatía hacia la santa porque se opuso de pleno cuando se enteró de que a su deseo de tomar el hábito lo hizo rodeada de sus criadas, desordenando la disciplinada vida de las monjas que allí habitaban y alterando las austeras normas por las que se regían. La decisión la interpretó como una humillación hacia su persona aunque, en el fondo, se trató de un 
intento fallido más por conquistar una independencia personal negada en sus años de matrimonio:

When Ruy died, Ana, who had ended by surrendering all her will and all her forgotten, buried self to his quiet, insistent domination, became invested with panic. A sense of total incompetence, of being a cripple, swept upon her. She felt angrily and somewhat madly in her grief, that her keeper had died either much too late or far too whoon. She felt a hreat too late or forte in her long subjugation... she decided -in pure hysteria - to be a nun. The episode was foolish and humiliating. It was the one attempt she had ever made to express a violence from within herself, and it failed pitifully...The memory of [her folly] was an unclosed wound in her vanity...Before Ruy had come to her she had lost her eye; immediately he left her she acted as a madwoman; and whilst he was there, gentle, considerate, devoted she had never been able to be anything but exactly his, as he made her. She was, it seemed, mutilated, tuerta-depleted in some sense she would never discover by the perfect taking over and direction of her life... (118)

Porque, como apunta acertadamente Suárez, Ana a lo largo de su vida ha tenido que "superar una constante reacción negativa a sus intentos de expresión anímica" (491), y aunque es plenamente consciente de que vive en pecado no está dispuesta a renunciar al placer ni a su propia realización personal a pesar de que le cueste la condena espiritual y los comentarios de todos los que la rodean

Now that she was by her own acknowledgement living a life of sin she did not cheat; feeling unrepentant, she did not feign repentance, and had to forgo the reception of the sacraments. Very often and very honestly now she looked in dismay at this impasse of her soul. But it had to stand. She saw no way of clearance save to give up her pleasure in Antonio Pérez. Living in mortal sin now, she knew that she what she was doing did not meriteternal hell in the eyes of any humew that she wondered... how theologians dared make categorical pronouncements. (190)

Parece como si por el mero hecho de ser mujer todo el mundo se siente con derecho a juzgar su conducta y a recriminar su relación amorosa, empezando por Escobedo que cuando se entera de que es amante de Antonio Pérez, su rival político, amenaza con informar al monarca, hasta su propio hijo Rodrigo que afea su conducta de malos modos. El mismo Felipe II, que aparece como un déspota autoritario e insensible, capaz de imponer su voluntad en las vidas privadas, se siente ultrajado por el hecho de que Ana tiene un amante, y, por tanto, siente que su vanidad ha sido herida. Las razones por las que el monarca se entromete en su intimidad no están del todo claras, generando distintas conjeturas. El mismo Antonio Pérez las intuye con claridad:

for if he doesn't love Ana, believe me, he loves the legend of their love, he loves the gossip and the echo of it, and its reminder of gayer days, he loves to think, perhaps, that only their shared love of Ruy prevented him and Ana from giving realty flagrant scandal long ago; also he loves to think that whatever he prizes no man touches save with his royal permission. He gave her to Ruy-so that was all right. But he's not giving her away again, whether or not he wants her...(80)
Ana se siente abandonada, y la única persona que está de su parte, salvo su fiel criada y su hija Anichu, es el cardenal Quiroga que condena sus amores adúlteros pero sabe respetar su decisión e incluso celebra su firmeza de espíritu al resistirse a la acción tiránica del rey:

...this stand of yours against blackmail is one of Spain's few good deeds at presentand I for one am glad to witness it...you ....are fighting quite simply for your idea of human conduct. If you've done wrong in the past-and you have-you are now doing something that is hard and right and cold and even disinterested. Moreover, you are acting in character..in this conflict with Philip you have been morally as

"Esa señora" era el término despectivo empleado por Felipe II para referirse a la que fuera en el pasado su confidente a la que llegó a admirar e incluso desear (los rumores de la época apuntaban a que mantuvieron relaciones amorosas y que el tercer hijo de Ana fue fruto de las mismas), y deja al descubierto su total animadversión hacia una persona que desafía conscientemente el poder real y se opone a su voluntad. Prueba de ello es su evolución a lo largo de la novela, desde las primeras páginas cuando en el papel de amigo íntimo de la familia se muestra preocupado por el bienestar de los hijos de Ana, a los últimos capítulos donde aparece su personalidad de ser supersticioso, acostumbrado a ejercer un poder absoluto incontestable, y cruel porque se alegra de que Ana, gracias a la condena impuesta, se deteriora físicamente y se vuelve vieja y desfigurada. Pero Ana triunfa anímicamente: acaba sus días con dignidad, sin claudicar ante los designios reales, aceptando ser víctima de un régimen autoritario y despótico pero sabiendo proteger en todo momento su intimidad. Se trata, en suma de un retrato idealizado de una mujer que vive de acuerdo con sus ideas y es capaz de sacrificar su reputación, poder y libertad a cambio de su derecho a vivir su vida a su manera. Como dice Dalsimer, "Ana de Mendoza becomes Kate O'Brien's most compelling portrait of the individualist, and, of all her heroines, the one who speaks loudest and most passionately for the author's commitment to self-expression" (86).

Era inevitable que más pronto o más tarde Kate O’ Brien dedicara un libro completo a Santa Teresa, porque desde 1934 que fue cuando empezó a leer sus obras por primera vez y a documentarse convenientemente sobre el periodo histórico que más le apasionaba, la Castilla imperecedera, la Castilla del siglo XVI, la del esplendor y de la decadencia, su arrolladora personalidad y la ingente tarea de reformadora que llevó a cabo, resultaban demasiado ricas y atractivas como para no tratarlas en extensión. De hecho, el personaje histórico de Ana de Mendoza originalmente lo encontró leyendo las cartas de Santa Teresa y en gran medida el personaje literario lo elaboró a partir del talante fuerte e independiente de la santa. Para Kate O' Brien ambas eran claros ejemplos de mujeres de acción, decididas, que lucharon denodadamente por su propia 
autonomía personal, para nada acomplejadas ante el poder. Su libro Teresa de Ávila no es un sesudo trabajo de investigación ni pretende tampoco llevar a cabo un estudio biográfico exhaustivo. Su propósito es más sencillo como explica en las primeras páginas:

The present attempt is a portrait, or rather, it is notes for a portrait; it is an apology not for Teresa but for this writer's constant admiration of her... I write of Teresa of Avila by choice which is passionate, arbitrary, personal. No one need agree with anything I have to say-but they must not, either, be hurt thereby. I am free to speak freely about a great woman. I am not writing of the canonized saint. I propose to freely abo examine Teresa, not by the rules of canonization, but for what she was-saint or
not-a woman of genius. And women of genius are few" (1993: 9-10)

El libro tiene el gran mérito de saber acercar de manera amena la figura de la santa al público de habla inglesa en general y, por otro lado, de destacar por encima de todo que fue una mujer que se comportó, actuó y escribió como una precoz feminista. Pero es precisamente su faceta como reformadora de la orden lo que más le impacta; tuvo que luchar con inteligencia, tenacidad, humildad, pero aún así provocó la ira de ciertas autoridades eclesiásticas que veían en su reforma una usurpación de su poder, y la envidia de algunas monjas que consideraban arrogante su deseo de establecer su propia institución. Fue vigilada de cerca, sometida al cerco de la Inquisición, se la ridiculizó, se le infundió miedo, y se le pusieron mil dificultades. Su determinación en llevar a cabo un ideal le acarreó numerosos enemigos y también unos pocos fieles incondicionales, y al final alcanzó la santidad. Su vida sólo puede ser admirada, no analizada con rigor, pues alcanzó un equilibrio difícil de obtener:

\begin{abstract}
"It is one of the marks of her genius hardest to convey to those who have not read her that this woman, whose flights into the ineffable and incommunicable might even by us, earthbound, be called crazy, never lost hold of her brilliant comigh even by us, eas bor through the net of her self-citicism. It is this exact bance of the scruptement through the net of her self-criticis. honest recorder and teacher against the impassioned, tortured mystic that keeps Teresa in her remarkable place in human history". (25)
\end{abstract}

Kate $\mathrm{O}^{\prime}$ Brien supo trasladar a sus obras las inquietudes y las ansiedades propias de nuestra época, en especial la lucha de la mujer moderna por construir una identidad coherente. Tanto Mary Lavelle como That Lady, en definitiva, abrieron camino dentro de su producción a otras novelas más donde la mujer asume un papel activo, muy alejado, desde luego, del que se promocionaba desde la esfera de la Iglesia Católica y del poder político tras la independencia y la proclamación del Estado Libre Irlandés.

REFERENCIAS BIBLIOGRÁFICAS
Dalsimer, A., Kate O'Brien. A Critical Study, Dublin, Gill and Macmillan, 1990

Hildebidle, J., Five Irish Writers: The Errand of Keeping Alive, Harvard, Harvard University Press, 1989.

Napier, T.S., “'External Impressions of Life': The Paradoxical Autobiographies of Kate O'Brien”, Patricia A. Lynch et at. (eds.), Back to the Present, Forward to the Past. Irish Writing and History since 1798, Vol.II, Amsterdam, Rodopi, 2006, pp. 27-40.

O’Brien, K., Mary Lavelle, London, Virago, 1984.

----, Farewell Spain, London, Virago, 1985.

----, That Lady, London, Virago, 1985.

----, Teresa of Avila, London, Mercier Press, 1993.

Reynolds, L.,"The Image of Spain in the Novels of Kate O'Brien”, Wolfgang Zach and H. Kosok (eds.) Literary Interrelations: Ireland, England and ther World, Vol. 3, Tübingen, Gunter Narr, 1988, pp 181-188.

Suárez Lafuente, M.S., "Entre el poder y la nada en Esa Dama de Kate O’Brien”, Archivum. Revista de la Facultad de Filología, 39-40, (1989-1990), pp. 485-496. 